\title{
Moderating Effect of Self-Esteem on the Relationship Between Optimism and Life Satisfaction in Final Year University Students
}

\author{
Samson F. Agberotimi ${ }^{1} \&$ Choja Oduaran ${ }^{1}$ \\ ${ }^{1}$ Lifestyle Diseases Research Entity, North West University, Mafikeng Campus, South Africa \\ Correspondence: Samson F. Agberotimi, Department of Psychology, Faculty of Health Sciences, North West \\ University, Private Bag X2046, Mmabatho, South Africa 2735. Phone: 27-65-641-2927 E-mail: \\ femiagberotimi@gmail.com
}

Received: November 6, 2019 Accepted: January 16, 2020 Online Published: February 9, 2020

doi:10.5539/gjhs.v12n3p12 URL: https://doi.org/10.5539/gjhs.v12n3p12

\begin{abstract}
This study examined the moderating effect of self-esteem on the relationship between optimism and life satisfaction in final year university students. A correlational survey design was utilized. Two hundred and twenty-three university final year students of a Nigerian university consisting of 124 males and 99 females aged $24.67 \pm 2.56$ participated in the study. Data were collected with a structured self-report questionnaire containing satisfaction with life scale $(\alpha=.82)$, Rosenberg self-esteem scale $(\alpha=.86)$, and life orientation test - revised $(\alpha$ $=.79$ ). Data were analyzed with SPSS v.23 at 0.05 significant level. Self-esteem significantly moderated the relationship between optimism and life satisfaction as indicated by a significant increase in proportion of the variance in life satisfaction when the interaction term between optimism and self-esteem was added to the regression model $[\Delta \mathrm{R} 2=.03, \Delta \mathrm{F}(1,219)=7.26, \mathrm{p}<.008, \mathrm{~b}=.188, \mathrm{t}(220)=2.69, \mathrm{p}<.01]$. It was concluded that the predictive impact of optimism on life satisfaction of university final year students is enhanced by their self-esteem; thus, students should be exposed to environment and program that promotes the development of high self-esteem and optimistic life orientation to enhance their well-being.
\end{abstract}

Keywords: life satisfaction, optimism, self-esteem, university students

\section{Introduction}

Academic years of university come with various changes and demands, and as study years progress, students are faced with an increase in mental stress as they take both a retrospective view and a prospective view of their academic achievement and challenges to come. This experience, is expected to have a significant impact on the overall well-being and subjective component of an individual's quality of life measure by life satisfaction of the students (sentence needs attention).

Investigating life satisfaction of students has become more needful considering the strong link the construct has with certain important outcomes such as adjustment, performance, and productivity, as well as other mental health realities. In 2010, Salmela-Aro and Tuominen- Soini argued for the relevance of research addressing life satisfaction of young people because of its close link effect on positive adjustment of young people. Similarly, a study conducted by Diener (2000) among college students from 17 different countries showed that students rated happiness and life satisfaction as important more than money, which implies that the students' view of their life satisfaction is very crucial to their functioning and overall well-being.

Life satisfaction can be defined as a sense of satisfaction or pleasure about one's present and past life. Generally, being satisfied with life means "having a favorable attitude toward one's life as a whole" (Haybron, 2007, p. 2). Life satisfaction has been widely considered to be a cognitive component of subjective well-being, defining happiness as an experience of feelings and emotions (Diener 1984; Schimmack \& Oishi, 2005). Furthermore, Daig, Herschbach, Lehmann, Knoll and Decker (2009) mentions that life satisfaction is synonymous with subjective well-being, quality of life or happiness. Life satisfaction has also been described in terms of assessment an individual makes about his/her life - an internal evaluation of the quality of life. In this context, "the meaning of life satisfaction is the person's attitude towards life in general or special aspects of life such as family life and learning experience" (Rezvan, Zahra, Maryam, \& Shima, 2016, p. 53).

As positive psychology becomes more popular, studies focusing on life satisfaction and associated factors such as 
optimism and self-esteem in different groups of people are on the increase. Optimism has been described in several ways. A general way of conceptualizing the concept, however, is the tendency to view and interpret life situations and future positively (Sheldon \& King, 2001). In this study, optimism is examined in the context of an individual's disposition, which reflects the attitude holds towards people, things, and situations with the expectancy of positive results in future events (Bryant \& Cvengros', 2004). In 2014, Friedman and Kern added that apart from reflecting one's expectation of positive outcome, optimism depicts confidence in one's ability to cope with challenges. Carver and Scheier (2014) are of the opinion that optimism functions the way it does because it is both a stable personality trait and a cognitive structure that guides a person's expectation of future positive events.

Several positive psychology studies among student populations have also shown that optimism is strongly associated with students' life satisfaction (e.g., Tuckwiller \& Dardick, 2018; Yalçin, 2011). In this regard, in their study among college students Yu and Luo (2018) found that dispositional optimism positively correlated with well-being. They further reported that individuals with higher levels of optimism are likely to have a higher general life satisfaction and more overall positive emotions. Rezaei and Khosroshahi (2018) also argued that optimism is closely related to life satisfaction because it is an acquired thinking style that motivates adaptive behavior even in the face of difficulties. Haar, Russo, Suñe, and Ollier-Malaterre (2014) asserted that by just thinking that one can perform or achieve the desired task positively is associated with a higher sense of life satisfaction. In this regard, it is assumed that students that perceive positive outcomes from their after school pursuit will be highly satisfied with their lives. Wilkins, Santilli, Ferrari, Nota, Tracey, and Soresi (2014) affirmed that students who endorsed the belief that things would "go their way" and that they can achieve their future goal tended to experience greater overall satisfaction.

Self-esteem, which is the self-evaluation of worthiness that can be inferred from the attitude a person holds toward $\mathrm{him} /$ herself (Kohn, 1994), is another variable that has consistently been found to be a determinant of mental health and well-being. Previous studies affirmed the positive impact of self-esteem on positive affect (Orth, Robins \& Widaman, 2012) as well as life satisfaction (Diener \& Diener, 1995, Ye, Yu, \& Li, 2012). Çivitci and Çivitci (2009) further substantiated the relationship between self-esteem and life satisfaction with the claim that the evaluation of one's self is crucial for the evaluation of one's life as a whole. In describing the relationship between self-esteem and life satisfaction, Zhang and Leung (2002), as well as Kong and You (2013) asserted that self-esteem is one of the most predictor variables of life satisfaction besides demographic characteristics, social relationships, and personality.

Overtime, self-esteem has been identified as one of the indicators of well-being among students. Kang, Shaver, Sue, Min and Jing (2003) reported a significant relationship between self-esteem and psychological well-being in undergraduate students. The results of a study among college students revealed significant correlations between self-esteem, hope, satisfaction with life, and mental health of the students (Rezaei, Bayani, \& Shariatnia, 2015). Similarly, Zhang, Zhao, Lester, and Zhou (2014) observed that life satisfaction among college students is positively associated with self-esteem. Olea, Bernal, and Hernandez (2012) further stated that students with high self-esteem are more positive, less anxious, more independent, less likely to engage in drugs and alcohol use, more confident and persistent at handling difficult tasks, happier and more sociable, and have better academic performance than those with low self-esteem.

Several studies have emphasized the effective impact of self-esteem as a third variable (mediator/moderator) in explaining relationships between variables (e.g., Acun- Kapıkıran, Körükçü, \& Kapıkıran, 2014; Ammirati, Lamis, Campos, \& Farber, 2015; Koruklu, 2015; Savi-Çakar, 2014). According to Robins, Trzesniewski, Tracy, Gosling, and Potter (2002), when it comes to predicting well-being, although optimism and resilience are stable factors, they may change and fluctuate within the steps of self-esteem's development. Thakur (2018), in his study among Indian undergraduate students, found significant inter-correlations between optimism, self-esteem, and life satisfaction. In another study among Chinese college students, Zhao, Wang, and Kong (2014) found that self-esteem significantly mediated the relationship between humor style and life satisfaction. The authors concluded that adaptive humor styles are likely may be associated with higher levels of life satisfaction by promoting the enhancement of one's tenuous feelings of self-worth (i.e., higher self-esteem).

Thus, from the aforementioned, there is a reason to suspect that self-esteem may moderate the relationship between optimism and life satisfaction. Furthermore, recent data suggest that increasing numbers of university students are experiencing poor mental health (Pinder-Amaker \& Bell, 2012). It has also been argued that mental health does not connote the mere absence of psychopathology, but also the presence of optimal psychological functioning and well-being (e.g., Renshaw \& Cohen, 2014). Understanding factors predicting psychological well-being of university students are, therefore, crucial in forming evidence-based interventions to promote 
students' well-being. In this vein, although a lot of findings on positive psychological constructs among higher learners are available in the public domain, the majority if these studies focused on first-year students and attempt to address issues of adjusting to the new school environment. In this regard, there is a paucity of findings on the well-being of students in the latter years of studies, particularly studies addressing the impact of self-esteem in explaining the relationship between optimism and life satisfaction among the Nigerian populace. Therefore, this study examined the mediatory effect of self-esteem on the relationship between optimism and life satisfaction. We intended to find out if students' sense of positive worth (self-esteem) optimizes or inhibit the relationship between optimism and life satisfaction.

\subsection{Objectives}

To achieve the set goal, this study was guided by objectives listed as follows:

1) To investigate the relationships between optimism, self-esteem and life satisfaction among university final year students; and

2) To examine the moderating effect of self-esteem on the relationship between optimism and life satisfaction of university final year students.

\section{Method}

\subsection{Design}

The study utilized a correlational survey design. The dependent variable was life satisfaction, while optimism was the independent variable, and self-esteem the moderating variable.

\subsection{Participants}

Two hundred and twenty-three (223) final year students of a University located in South West, Nigeria, selected through a purposive sampling technique participated in the study. , The majority of the respondents, 124 (55.6\%), were males. Participants' ages ranged between 19 to 33 years with a mean age 24.67 years and a standard deviation of 2.56 .

\subsection{Instrument}

A structured self-report questionnaire containing instruments with sound psychometric properties was used to collect data in this study. The questionnaire was made up of four sections.

Section one: This section contains information on demographic attributes of respondents, which include gender, age, religious affiliation, and family background.

Section two: Satisfaction with life scale (SLS): The SLS is a 5-item scale developed by Diener, Emmons, Larsen, \& Griffin, (1985). The scale was developed to assess a respondent's satisfaction with life as a whole. The scale does not assess the satisfaction with life domains such as health or finances but allows subjects to integrate and weigh these domains in the way they choose. Each item on the scale is scored from 1 to 7 in terms of "strongly agree" to "strongly disagree." A total score was calculated from the five items, the range being 5 to 35 . A score of 20 is the middle point so higher scores indicate high satisfaction with life. The scale has been reported to consistently show good psychometric properties and has been used in several studies. For example, Abolghasemi, and Varaniyab, (2010) reported an alpha reliability co-efficient of .82. Cronbach's alpha 0.74 was established as the reliability coefficient in the present study.

Section three: Life orientation test - revised (LOT-R): The LOT-R was designed by Scheier, Carver, \& Bridges (1994) to assess individual differences in generalized optimism versus pessimism. The LOT-R is a 10-item measure of optimism versus pessimism. Of the ten items, three items (1, 4 and 10) measure optimism, three items $(3,7$, and 9) measure pessimism, and four items $(2,5,6$, and 8$)$ serve as fillers. Each item was rated on a 5-point Likert scale ( $0=$ "I disagree a lot", 4 = "I agree a lot"), therefore scores range from 0 to 12 on both optimism and pessimism subscales, making a maximum possible composite score of 24. Scheier et al. (1994) reported the scale's norm as $\mathrm{M}=14.23$, $\mathrm{S} . \mathrm{D}=4.0$ (total); $\mathrm{M}=7.46, \mathrm{~S} . \mathrm{D}=2.6$ (optimism); and $\mathrm{M}=5.22$, $\mathrm{S} . \mathrm{D}=2.1$ (pessimism). The test is found to be reliable with Cronbach's alpha 0.78 reported by the author. Reliability coefficient Cronbach's alpha 0.79 was established in this study.

Section four: Rosenberg Self-esteem Scale: Rosenberg Self-Esteem Scale (Rosenberg, 1965) is a ten-item scale with response options strongly agree, agree, disagree and strongly disagree. The scale comprised of statements dealing with general feelings and evaluation individuals hold about themselves, and is scored in the following way: $\mathrm{SA}=4, \mathrm{~A}=3, \mathrm{D}=2, \mathrm{SD}=1$. Items $2,5,6,8$, and 9 are reverse scored. The 10 items score are sum to obtain self-esteem score. Score ranges between 10 and 40, the higher the score, the higher the self-esteem. The scale was also found 
reliable with Cronbach's alpha 0.86 in the present study

\subsection{Procedure}

Detailed statement of informed consent that contained the purpose, procedures, potential risk(s) (if any) and benefits of participating in the study was given and explained to participants. Participants were also assured of the confidentiality of their responses. Individuals who consented voluntarily to participate in the study administered the research questionnaire. Participants were approached at different locations including lecture theatres and lounge. Data was collected throughout two (2) weeks. Two hundred and fifty (250) questionnaires were administered, while two hundred and twenty-three (223) were usable for data entry and analysis.

\subsection{Data Analysis}

Data collected were subjected to the Statistical Package for Social Scientist version 23 for statistical analysis. Descriptive statistics, Pearson product-moment correlation, and hierarchical regression analysis were used to analyze the data, and results were accepted at $\mathrm{p} \leq 0.05$.

\section{Results}

The report of the focus group discussions as obtainable from network analysis conducted with the use of Atlas to software revealed the reasons why the participants engage in non-medical use of pharmaceutical drugs and the consequences that follow, and intention to stop the use.

\subsection{Objective 1}

To investigate the relationships between optimism, self-esteem, and life satisfaction among university final year students.

\section{Correlations and Descriptive statistics}

The results presented in Table 1 shows the descriptive statistics for the variables. Correlation analysis that was conducted to determine the relationships between the research variables was also obtained on the Table.

Table 1. Descriptive Statistics and Correlations among Variables

\begin{tabular}{|c|c|c|c|c|c|c|c|c|}
\hline & & Mean & SD & 1 & 2 & 3 & 4 & 5 \\
\hline 1 & Life satisfaction & 25.43 & 4.99 & - & & & & \\
\hline 2 & Self-esteem & 19.62 & 5.09 & $.38^{* *}$ & - & & & \\
\hline 3 & Optimism & 9.85 & 2.06 & $.22^{* *}$ & .13 & - & & \\
\hline 4 & Age & 24.67 & 2.56 & $.20^{* *}$ & .04 & & - & \\
\hline 5 & Sex & .66 & .48 & -.01 & .01 & -.05 & .08 & - \\
\hline
\end{tabular}

For Gender, the male is coded as 1 while female as 2

Results of the correlation analysis (see Table 1) revealed the relationships between age, sex, self-esteem, optimism, and life satisfaction among the final-year university students. The result showed that age $(r=.20, p<.01)$, self-esteem $(\mathrm{r}=.38, \mathrm{p}<.01)$, and optimism $(\mathrm{r}=.22, \mathrm{p}<.01)$ significantly positively correlated with life satisfaction. On the other hand, there was no significant relationship between sex and life satisfaction $(r=-.01, p>.05)$.

\subsection{Objective 2}

To examine the moderating effect of self-esteem on the relationship between optimism and life satisfaction of university final year students.

\section{Moderation analysis}


Table 2. Summary of Hierarchical Regression showing the moderating effect of self-esteem on the relationship between optimism and life satisfaction

\begin{tabular}{|c|c|c|c|c|c|c|c|c|}
\hline & $\mathrm{B}$ & SE B & $\mathrm{B}$ & $\mathbf{T}$ & $\mathbf{R}^{2}$ & $\Delta \mathrm{R}^{2}$ & $\mathrm{~F}$ & $\Delta \mathrm{F}$ \\
\hline Step 1 & & & & & .23 & .23 & $25.12^{* * *}$ & $25.12^{* * *}$ \\
\hline Self-esteem & .45 & .08 & .42 & $6.21^{* * *}$ & & & & \\
\hline Optimism & .46 & .18 & .17 & $2.56^{*}$ & & & & \\
\hline Step 2 & & & & & .26 & .03 & $19.78^{* * *}$ & $7.25^{* *}$ \\
\hline Self-esteem & .39 & .07 & .36 & $5.15^{* * *}$ & & & & \\
\hline Optimism & .51 & .18 & .19 & $2.83^{* *}$ & & & & \\
\hline Self-esteem*optimism & .10 & .04 & .18 & $2.69^{* *}$ & & & & \\
\hline
\end{tabular}

$* * * \mathrm{p}<.001, * * \mathrm{p}<.01, * \mathrm{p}<.05$.

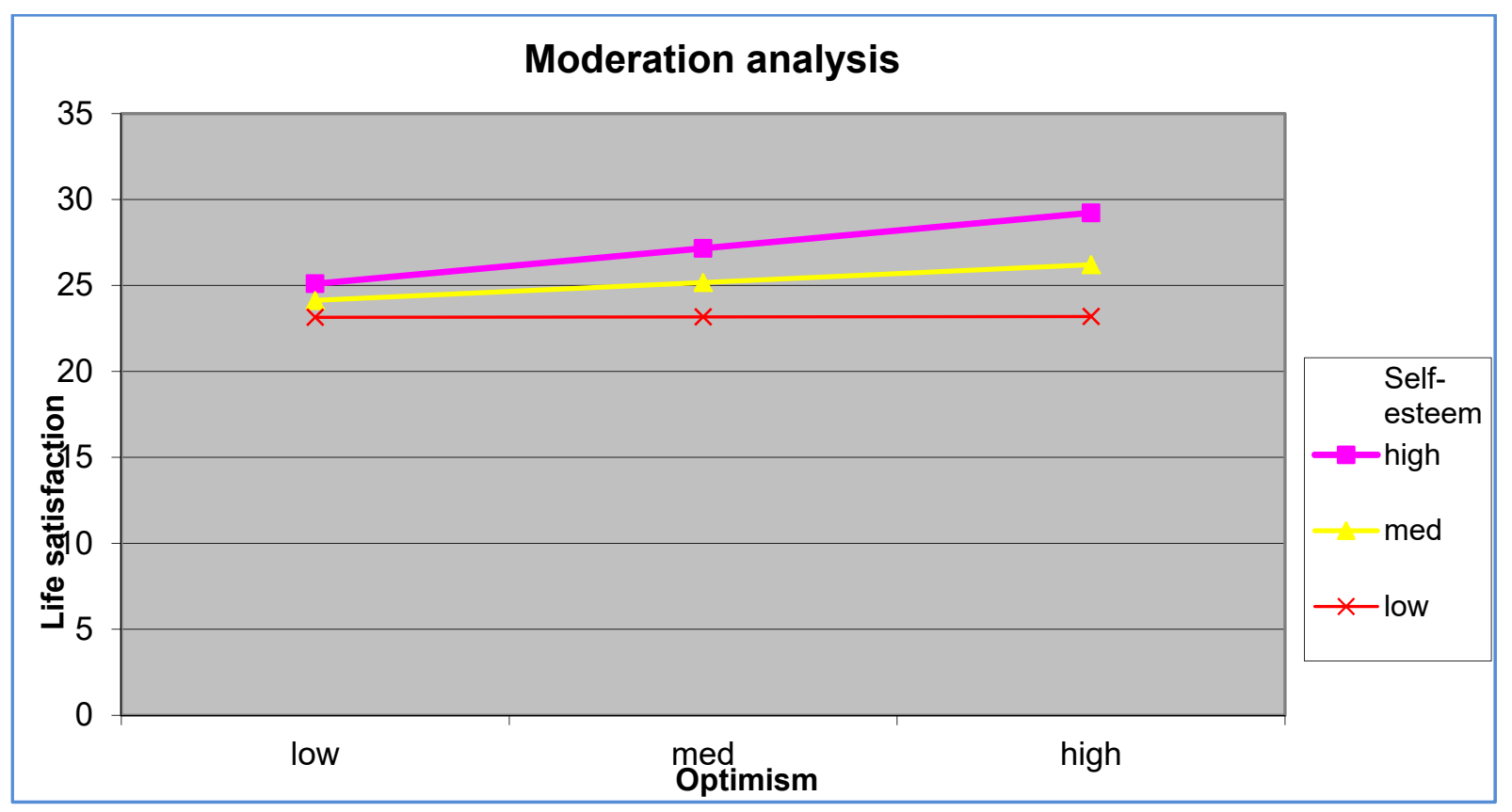

Figure 1. Interaction between self-esteem and optimism on life satisfaction

To test the hypothesis that self-esteem moderates the relationship between optimism and life satisfaction of university final year students, a hierarchical multiple regression analysis was conducted. From the results presented in Table 2, in the first step, two variables were included: optimism and self-esteem. These variables accounted for a significant amount of variance in life satisfaction, $\mathrm{R}^{2}=.228, \mathrm{~F}(2,220)=25.12, \mathrm{p}<.001$. To avoid potentially problematic high multicollinearity with the interaction term, the variables were centered, and an interaction term between optimism and self-esteem was created (Aiken \& West, 1991).

Next, the interaction term between optimism and self-esteem was added to the regression model, which accounted for a significant proportion of the variance in life satisfaction, $\left[\Delta \mathrm{R}^{2}=.03, \Delta \mathrm{F}(1,219)=7.26, \mathrm{p}<.001, \mathrm{~b}=.188, \mathrm{t}\right.$ $(220)=2.69, \mathrm{p}<.01]$.

Examination of the interaction plot (Fig 1) showed an enhancing effect that as optimism and self-esteem increased, life satisfaction increased. At low optimism, students' life satisfaction was similar for with low, average, or high self-esteem. Students with high optimism and high self-esteem, however, reported the highest life satisfaction.

\section{Discussion}

The purpose of this study is to examine whether or not self-esteem moderates the relationship between optimism and life satisfaction among final year undergraduate students of a Nigeria university. 
The result of this study on the significant positive inter-relationships found between optimism, self-esteem and life satisfaction among students supported previous findings (e.g., Ammirati, et al., 2015; Rezaei et al., 2018; Thakur, 2018) establishing that students who are optimistic and with high self-esteem also report high life satisfaction.

With regard to examining the effect of self-esteem on the predictive impact of optimism on life satisfaction, a hierarchical multiple regression analysis was conducted, while the interaction graph was plotted utilizing the ModGraph. In line with the expectation that high optimistic students with high self-esteem will report higher life satisfaction, a positive relationship optimism, and life satisfaction, as well as self-esteem and life satisfaction. More importantly, as established by the moderation model, self-esteem enhances the relationship between optimism and life satisfaction. The level of life satisfaction reported by high optimistic persons who also manifest high self-esteem was found to be higher than that of persons with high optimism but lower self-esteem.

This finding is in agreement with several empirical kinds of literature. For instance, Wilkins et al. (2014) argued that students who endorsed the belief that things would "go their way" and that they can achieve their future goal tended to experience greater overall satisfaction. The previous finding has also shown self-esteem is a potent third variable in explaining relationships between variables. In a related study by Robins et al., (2002), self-esteem was established as an effective moderating variable in the prediction of well-being by optimism and resilience. Finally, the finding of this study is further reinforced by the report of Zhao et al., (2014) that self-esteem significantly mediated the relationship between humor style and life satisfaction of college students.

\subsection{Limitation of the Study}

One of the core limitations of this study is the small sample size of the participants included in this study, which weakens the generalizability of the findings to the entire final year university student population in Nigeria. In this vein, future similar studies with wider coverage in terms of large sample size is recommended. Furthermore, variables such as socio-demographic and economic factors were not accounted for and possibly controlled for in the regression model of this study. These variables have been shown in previous studies to have a significant impact on the life satisfaction of students. It is believed that if future research puts into special consideration these socio-demographic and economic variables, more valuable information will be available in explaining the moderating effect of self-esteem on the relationship between optimism and life satisfaction, thus further advance the knowledge base of positive psychology among Nigerian population.

Nevertheless, this study has certain strengths that should be highlighted. The major advantage of this study is the focus on university final year students, among whom the moderating effect of self-esteem on the predictive impact of optimism on self-esteem was observed. In addition, considering the paucity of empirical literature that is available in the public domain, this study provided a valuable contribution to what is known about factors influencing life satisfaction among the target population in Nigeria.

\section{Conclusion}

It was concluded that the predictive impact of optimism on life satisfaction of university final year students is enhanced by their self-esteem. Putting the important roles of optimism and self-esteem in promoting the psychological well-being of university students, programs targeting the development and enhancement of an optimistic mindset and positive self-worth of students should be incorporated and reinforced as other curricular activities of students in the higher institutions.

\section{Competing Interests Statement}

The authors declare that there are no competing or potential conflicts of interest.

\section{References}

Abolghasemi, A., \& Varaniyab, S. T. (2010) Resilience and perceived stress: Predictors of life satisfaction in the students of success and failure. Procedia Social and Behavioral Sciences 5, 748-752. https://doi.org/10.1016/j.sbspro.2010.07.178

Acun-Kapıkıran, N., Körükçü, Ö., \& Kapıkıran, Ş. (2014). Erken ergenlikte anne-baba tutumlarının yaşam doyumu ve depresyonla ilişkisi: Benlik saygısının aracılık rolü [The relation of parental attitudes to life satisfaction and depression in early adolescents: The mediating role of self-esteem]. Educational Sciences: Theory \& Practice, 14, 1237-1252. http://doi.org/10.12738/estp.2014.4.2137

Ammirati, R. J., Lamis, D. A., Campos, P. E., \& Farber, E. W. (2015). Optimism, well-being, and perceived stigma in individuals living with HIV. AIDS Care, 27, 926-933. https://doi.org/10.1080/09540121.2015.1018863

Bryant, F. B., \& Cvengros, J. A. (2004). Distinguishing hope and optimism: Two sides of a coin, or two separate 
coins? Journal of Social and Clinical Psychology, 23, 273-302. http://doi/10.1521/jscp.23.2. 273.31018

Carver, C. S., \& Scheier, M. F. (2014). Dispositional optimism. Trends in Cognitive Sciences, 18, 293-299. https://doi.org/10.1016/j.tics.2014.02.003

Çivitci, N., \& Çivitci, A. (2009). Self-esteem as mediator and moderator of the relationship between loneliness and life satisfaction in adolescents. Personality and Individual Differences, 47, 954-958. http://doi.org/10.1016/j.paid.2009.07.022

Daig, I., Herschbach, P., Lehmann, A., Knoll, N., \& Decker, O. (2009). Gender and Age Differences in Domain-Specific Life Satisfaction and the Impact of Depressive and Anxiety Symptoms: A General Population Survey from Germany. Quality of Life Research, 18 (6), 669-678. https://doi.org/10.1007/s11136-009-9481-3

Diener, E. (1984). Subjective well-being. Psychological Bulletin, 95, 542-575. https://doi.org/10.1037/0033-2909.95.3.542

Diener, E. (2000). Subjective well-being: The science of happiness and a proposal for a national index. American Psychologist, 55(1), 34-43. https://doi.org/10.1037/0003-066X.55.1.34

Diener, E., \& Diener, M. (1995). Cross-cultural correlates of life satisfaction and self-esteem. Journal of Personality and Social Psychology, 68, 653-663. https://doi.org/10.1037/0022-3514.68.4.653

Diener, E., Emmons, R. A., Larsen, R. J., \& Griffin, S. (1985). The Satisfaction With Life Scale. Journal of Personality Assessment, 49(1), 71-75. https://doi.org/10.1207/s15327752jpa4901_13

Friedman, H.S., \& Kern, M.L. (2014). Personality, well-being, and health. Annual Review of Psychology, 65, 719-742. https://doi.org/10.1146/annurev-psych-010213-115123

Haar, J. M., Russo, M., Suñe, A., \& Ollier-Malaterre, A. (2014). Outcomes of work-life balance on job satisfaction, life satisfaction and mental health: A study across seven cultures. Journal of Vocational Behavior, 85, 361-373. https://doi.org/10.1016/j.jvb.2014.08.010

Haybron, D. (2007). Life satisfaction, ethical reflection, and the science of happiness. Journal of Happiness Studies, Springer, 8(1), 99-138. https://doi.org/10.1007/s10902-006-9006-5

Kang, S., Shaver, P., Sue, S., Min, K., \& Jing, H. (2003). Culture-specific Patterns in the Prediction of Life Satisfaction: Roles of Emotion, Relationship Quality, and Selfesteem. Personality and Social Psychology Bulletin, 29, 1596-1608. https://doi.org/10.1177/0146167203255986

Kohn, A. (1994). The truth about self-esteem. Phi Delta Kappan, 76, 272-283.

Kong, F., \& You, X. (2013). Loneliness and self-esteem as mediators between social support and life satisfaction in late adolescence. Social Indicators Research, 110(1), 271-279. https://doi.org/10.1007/s11205-011-9930-6

Koruklu, N. (2015). Personality and social problem-solving: The mediating role of self-esteem. Educational Sciences: Theory \& Practice, 15, 481-487.

Olea, M. T., Bernal, M. M., \& Hernandez, R. M. (2012). Self-esteem and its correlates among University Freshmen Biotechnology Major. International Journal of Educational Research and Technology, 3(3), 64-70.

Orth, U., Robins, R. W., \& Widaman, K. F. (2012). Life-span development of self-esteem and its effects on important life outcomes. Journal of Personality and Social Psychology, 102, 1271-1288. https://doi.org/10.1037/a0025558

Pinder-Amaker, S., \& Bell, C. (2012). A bioecological systems approach for navigating the college mental health crisis. Harvard Review of Psychiatry, 20(4), 174-188. https://doi.org/10.3109/10673229.2012.712842

Renshaw, T. L., \& Cohen, A. S. (2014). Life satisfaction as a distinguishing indicator of college student functioning: Further validation of the two-continua model of mental health. Social Indicators Research, 117, 319-334. https://doi.org/10.1007/s11205-013-1342-7

Rezaei, A., \& Khosroshahi, J. B. (2018). Optimism, social intelligence and positive affect as predictors of university students' life satisfaction. European Journal of Mental Health 13, 150-162. https://doi.org/10.5708/EJMH.13.2018.2.3

Rezaei, T., Bayani, A. A., \& Shariatnia, K. (2015). The prediction of mental health based on variables of Self-esteem, life satisfaction and hope among College students. Iran Journal of Health Education and Health Promotion, 3(3), 242-252. 
Rezvan, H., Zahra, D. B., Maryam, S. M. G. \& Shima, H. (2016). Relationship between Optimism, Religiosity and Self-Esteem with Marital Satisfaction and Life Satisfaction. International Education Studies, 9(6), 53-61. https://doi.org/10.5539/ies.v9n6p53

Robins, R. W., Trzesniewski, K. H., Tracy, J. L., Gosling, S. D., \& Potter, J. (2002). Global self-esteem across the life span. Psychology and Aging, 17(3), 423-434. https://doi. org/10.1037/0882-7974.17.3.423

Rosenberg, M. (1965). Society and the adolescent self-image. Princeton, NJ: Princeton University Press.

Salmela-Aro, K., \& Tuominen-Soini, H. (2010). Adolescents' life satisfaction during the transition to post-comprehensive education: Antecedents and consequences. Journal of Happiness Studies, 11, 683-701. https://doi.org/10.1007/s10902-009-9156-3

Savi-Çakar, F. (2014). Otomatik düşüncelerin umutsuzluk üzerindeki etkisinin incelenmesi: Benlik saygısının aracilık rolü [The effect of automatic thoughts on hopelessness: Role of self-esteem as a mediator]. Kuram ve Uygulamada Eğitim Bilimleri, 14, 1-16. https://doi.org/10.12738/estp.2014.5.2132

Scheier, M. F., Carver, C. S., \& Bridges, M. W. (1994). Distinguishing optimism from neuroticism (and trait anxiety, self-mastery, and self-esteem): A re-evaluation of the Life Orientation Test. Journal of Personality and Social Psychology, 67(6), 1063-1078. https://doi.org/10.1037/0022-3514.67.6.1063

Schimmack, U., \& Oishi, S. (2005). The influence of chronically and temporarily accessible information on life satisfaction judgments. Journal of Personality and Social Psychology, 89(3), 395-406.https://doi.org/10.1037/0022-3514.89.3.395

Sheldon, K. M., \& King, L. (2001). Why positive psychology is necessary. American Psychologist, 56, 216-217. https://doi.org/10.1037/0003-066X.56.3.216

Thakur, M. B. (2018). Examining the Association between Hope, Optimism, Self-esteem and Life Satisfaction: The Indian Context. Journal of Psychological research, 13(1), 23-31. https://doi.org/10.32381/JPR.2018.13.01.3

Tuckwiller, B., \& Dardick, W. R. (2018). Mindset, Grit, Optimism, Pessimism And Life Satisfaction In University Students With And Without Anxiety And/Or Depression. Journal of Interdisciplinary Studies in Education, $6(2), 32-48$.

Wilkins, K. G., Santilli, S., Ferrari, L., Nota, L., Tracey, T. J. G., \& Soresi, S. (2014). The relationship among positive emotional dispositions, career adaptability, and satisfaction in Italian high school students. Journal of Vocational Behavior, 85, 329-338. https://doi.org/10.1016/j.jvb.2014.08.004

Yalçin, I. (2011). Social support and optimism as predictors of life satisfaction of college students. International Journal for the Advancement of Counseling, 33, 79-87. https://doi.org/10.1007/s10447-011-9113-9

Ye, S., Yu, L., \& Li, K.K. (2012). A cross-lagged model of self-esteem and life satisfaction: Gender differences among Chinese university students. Personality and Individual Differences, 4, 546-551. https://doi.org/10.1016/j.paid.2011.11.018

Yu, Y., \& Luo, J. (2018). Dispositional Optimism and Well-Being In College Students: Self-Efficacy as a Mediator. Social Behavior and Personality, 46(5), 783-792. https://doi.org/10.2224/sbp.6746

Zhang, J., Zhao, S., Lester, D., \& Zhou, C. (2014). Life satisfaction and its correlates among college students in China: a test of social reference theory. Asian Journal of Psychiatry, 10, 17-20. https://doi.org/10.1016/j.ajp.2013.06.014

Zhang, L., \& Leung, J. (2002). Moderating effects of gender and age on the relationship between self-esteem and life satisfaction in mainland Chinese. International Journal of Psychology, 37, 83-91. https://doi.org/10.1080/00207560143000252

Zhao, J., Wang, Y., \& Kong, F. (2014). Exploring the mediation effect of social support and self-esteem on the relationship between humor style and life satisfaction in Chinese college students. Personality and Individual Differences, 64, 126-130. https://doi.org/10.1016/j.paid.2014.02.026

\section{Copyrights}

Copyright for this article is retained by the author(s), with first publication rights granted to the journal.

This is an open-access article distributed under the terms and conditions of the Creative Commons Attribution license (http://creativecommons.org/licenses/by/4.0/). 